\title{
THE IMPACT OF RELATIONS WITH STAKEHOLDERS ON CHANGE MANAGEMENT, INNOVATION AND COMPETITIVENESS OF THE ORGANIZATION ON THE EXAMPLE OF THE CURRENT ECONOMIC SITUATION OF ENTERPRISES IN POLAND
}

\author{
Marta WIĄCEK \\ EMBA INE PAN, CFO; mwiacek3@poczta.onet.pl, ORCID: 0000-0002-1857-3080
}

\begin{abstract}
Purpose: The purpose of this article is to systematize knowledge about organizations' relationships with their stakeholders and to highlight the connection and impact that managing these relationships and functioning in their network can have on them: an organization's capacity for innovation, change management efficiency and competitive advantage.

Design/methodology/approach: Approach to the subject of the paper is theoretical in its first part and in the second one is based on the case study methodology conducted in chosen organization in Poland. On the basis of the literature, the basic variables influencing the accumulation of effects that can be achieved by an organization that effectively uses the synergy of all mentioned phenomena have been analysed. The examples of organizations in Poland applying such activities in the current economic situation were cited.

Findings: Organisations which deal with difficult market situation should flexibly: use support from their stakeholders, take the risk of innovation and using both of the above try to implement and manage necessary changes efficiently and quickly. All these phenomena as well as the way of dealing with them make coping with hard situation easier.

Practical implications: Article's analysis and general view confirmes the significant economic and business impact on maintaining and increasing the competitive advantage of organizations using all mentioned phenomena to deal with difficulties of global market. Mentioned positive practical effects on enterprises prove how high the potential is created as a result of combining management of relations with stakeholders on competitiveness, innovation and the ability to manage organizational change.

Originality/value: The interactions and effects of the impact on the organization of: stakeholders relations, networks and change management - that have already been scientifically described many times were emphasized because only in a few sectors of the economy their' coexistence and its effects on the organization are clearly visible, observable and possible to describe.
\end{abstract}

Keywords: stakeholder relations, networks, change, change management, competitiveness.

Category of the paper: General review; Viewpoint. 


\section{Introduction}

In the primary sources, it is most often emphasized how difficult it is for companies to function in a changeable and highly competitive market environment in the conditions of constantly intensifying competitive struggle. At present, however, we can observe the opposite phenomenon of positive effects of enterprises functioning in the network of various relations with the environment. It spread widely during the viral pandemic. The companies are currently not forced to look for alternative sources of competitive advantage, but as can be observed, they gain it and maximize it through mutual maintenance of relations resulting from mutual cooperation. Thus, we are dealing with the phenomenon of multidimensional, mutual support for organizations from contract stakeholders. Its measurable effect is easier to overcome the difficult market situation and economic crisis caused by the global pandemic. Therefore, cooperation based on building lasting relationships with stakeholders has become an even more important competitive advantage. This article will systematize knowledge in this area.

\section{The Stakeholder Concept - Extract}

There are two approaches to stakeholder definition in management theory. The first, traditional approach, assumes that these are "owners" who have a dominant and direct influence on the functioning of the entity (Downar, Niedzielski, 2006; Freeman, 2013). The second one, on the other hand, assumes a broader perspective on stakeholder issues. It assumes that these are "entities (individuals, communities, institutions, organizations, offices) that can influence and are influenced by the company" (Freeman, Moutchnik, 2013). Thus, they are specific, identifiable entities that constitute the environment of a company, enter into direct or indirect relations with it of various kinds and can facilitate or hinder its functioning (Downar, Niedzielski, 2006). This concept was introduced to the management science by R.E. Freeman using it for the first time in 1979 in his work "Strategic Management: A Stakeholder Approach". (Freeman, 1984) He defined stakeholders as "any individual or group that can influence or be influenced by an organization in pursuit of its goals. An important element of this definition is the impact that exists between stakeholders and the organization. It can be diverse in nature. Stakeholders can influence a particular organization, and an organization can influence its stakeholders. Donaldson's and Preston's definition of a stakeholder is also relevant to this discussion, which means that stakeholders are individuals or groups that have direct or indirect contracts with an organization. If a contract is defined broadly as an informal or formal contract that binds both parties (the organization and its stakeholders), then it can be concluded that a stakeholder can be virtually any element of the organization's proximate and distant 
environment. As a result of such an approach to the definition of an organization's stakeholder, the contractual context in which the relationship is embedded will be important. The provisions of the agreement may limit or inversely impose the type of mutual cooperation, determine mutual interactions and influences. Moreover, it should also be noted here that in the case of contractual relations, the whole organization is not always the subject of interaction with a stakeholder. Very often, in economic practice, it can only be a specific process, a system element or a project limited in time (Civera, Freeman, 2019). However, most often, in the environment of most companies currently operating on the market, classic groups of stakeholders can be distinguished:

- customers, suppliers;

- employees, owners;

- NGOs;

- local communities;

- investors;

- banks, media, state administration.

Depending on the sector of the organization's activity, each of these groups has a different weight for a given entrepreneur. The literature on the subject also lists several other possible ways of classifying the stakeholders and thus making their division into groups according to several criteria. From the point of view of this analysis the most important criterion is the type of relationship existing between the stakeholders and the organization. It allows to classify the stakeholders into:

- Consubstantial stakeholders - these are the entities that co-create the organization and operate within it, such as employees, owners, shareholders.

- Contractual stakeholders - their relations with the organization are based on business, contractual activities, e.g. suppliers, various types of cooperators.

- Contextual stakeholders - they do not have direct contact with the organization, most often they are groups working for the benefit of communities, influencing a positive image and acceptance of the company's activity on the market. Examples are local and social communities or institutions.

The classification presented above is shown in Figure 1.

\begin{tabular}{|l|l|}
\hline Consubstantial stakeholders & $\bullet$ employees \\
& $\bullet$ owners \\
\hline Contractual stakeholders & $\bullet$ recipients \\
& $\bullet$ suppliers \\
& $\bullet$ financial institutions \\
\hline Contextual stakeholders & $\bullet$ competitors \\
& $\bullet$ public administration \\
\hline
\end{tabular}

Figure 1. Stakeholder breakdown by type of relationship with the company. Source: Rodriguez, M.A., Ricar, J.E. (2002). Towards the sustainable business. Revista de Antiquos Alumnos, IESE Universidad Navarra, 86, 30-32. 
Consubstantial stakeholders have a close relationship with the organization. They are strongly connected with the organization and are usually personally involved in its development. Contractual stakeholders are those entities or individuals who, on the basis of ongoing contracts or orders, cooperate with the organization on a more or less long-term basis. These entities are interested in its further welfare. Sometimes, depending on the relationship they have built, they may also be involved in maintaining and developing it. Contextual stakeholders will be more closely associated with the organization if it operates in a strong relationship with local communities. This bond, or relationship, is a two-way impact between cooperating stakeholders and the organization. This relationship can take many forms. Starting from direct market contact, through the relationship resulting from an existing agreement between the entities or other formalized business relationship such as for example: strategic alliance, cluster or consortium. It therefore includes cooperation aimed at achieving the objectives of both parties. It is therefore a phenomenon characterized by bilateralism, voluntariness and active involvement in the existing relationship (Wiatrak, 2014). The multidimensionality and duality of the relationship causes that this type of relationship between entities can be both cooperative and competitive. From the point of view of an organization, it may have more or less value for it. It can be created by material expenditure, i.e., simply real material benefits, investments that have to be made in order to execute this relationship, or non-material investments that have to be incurred in order to actually confirm the existence of a relationship between organizations. In the context of analyzing its value for an organization, in simple terms, this is the difference between the benefits it can derive from it and the expenses it must incur to sustain it (Zeithaml, 1988; Piwoni-Krzeszowska, 2013). The sources of relations should be sought in the following dimensions of the organization:

- $\quad$ economic - gives the possibility to reduce costs or increase revenues;

- $\quad$ product or service - allows to increase the value of the relationship meeting the needs of entities;

- beahavioural - intangible aspects such as maintaining trust, culture of relations, its further development;

- organizational - enables realization of processes between entities in relation to synchronization of standards, information exchange processes, etc.;

- $\quad$ strategic - strengthening of competitive advantage, strengthening key competences, creating market position (Piwoni-Krzeszowska, 2013).

The value of the relationship as many other types of assets owned by the organization can be managed. This enables the organization to build a wide range of relations with other entities from the environment - optimal and useful for it at a given strategic moment. In order to maximize the desired effects, it is necessary to map the sources of relationship value and establish, in a thoughtful way, a strategy for managing the relationship itself. Only such action will allow to generate the benefits expected by the organization in a longer time spectrum (Piwoni-Krzeszowska, 2013). Stakeholder relationship management is a process which - 
to enable the organization to identify, build and maintain relations - should be carried out according to the following stages:

- identification of stakeholders with a distinction between external and internal stakeholders;

- $\quad$ analysis and diagnosis of interests/goals;

- formulation of appropriate strategies;

- $\quad$ implementation of the strategy (Downar Niedzielski, 2006).

Properly conducted diagnosis and stakeholder analysis will lead to the creation of opportunities to manage the relationships arising or already existing between them and the organization. It will also make it possible to establish a hierarchy of their importance, diagnosing the risks associated with their existence. A well-thought-out relationship management strategy can lead to a higher expected added value for the organization. The increase of relationship potential, achieved by appropriate relationship management and its value, can also be maximized. To this end the organization should use the factors influencing the relationship. The following groups are distinguished in the literature:

- relationship factors independent of the organization - they are beyond the possibility of shaping their influence on the company being a party of the relationship;

- relational factors depending on the organization which is a party to the relationship, e.g. satisfactory commercial conditions, readiness to synchronize, improving reputation, recommending to other entities, using informal relations, trust, loyalty, offering discounts, installment sales; informing the market about a joint offer or cooperation.

A consequence of striving for thoughtful relationship management and increase in its value is also the possibility of developing a model of stakeholder relationship management adapted to the specificity of a given company. An exemplary management model is presented in Table 1.

Table 1.

Organisation Relationship Management Model

\begin{tabular}{|l|l|}
\hline 1. Planning & Execution stage \\
\hline Preparatory stage & $\begin{array}{l}\text { - internal and inter-organisational arrangements } \\
\text { - activation of the relationship conditions } \\
\text { - evaluation }\end{array}$ \\
\hline $\begin{array}{l}\text { - reflection on the role of relationships } \\
\text { - analysis of company potential }\end{array}$ & Execution stage \\
\hline 2. Organising & \begin{tabular}{l} 
- coordination in the area of processes, structures, \\
strategies \\
\hline Preparatory stage
\end{tabular} \\
\hline $\begin{array}{l}\text { - selection of entities and forms of cooperation } \\
\text { - collaboration } \\
\text { - design of information and decision making } \\
\text { systems }\end{array}$ & - evaluation \\
\hline
\end{tabular}


Cont. table 1.

\begin{tabular}{|l|l|}
\hline 3. Motivating & Execution stage \\
\hline Preparatory stage & $\begin{array}{l}\text { - exchange of information and experience } \\
\text { - system of values and relational norms } \\
\text { - implementation of the incentive system } \\
\text { - evaluation }\end{array}$ \\
\hline $\begin{array}{l}\text { - developing an incentive system } \\
\text { - identification of motivational incentives }\end{array}$ & Execution stage \\
\hline 4. Control & $\begin{array}{l}\text { - current assessment of the status of relations } \\
\text { - deviation analysis } \\
\text { - expected status of the relationship }\end{array}$ \\
$\begin{array}{l}\text { - ratings } \\
\text { - monitoring }\end{array}$ & $\begin{array}{l}\text { - evaluation } \\
\text { - scenarios of possible events }\end{array}$
\end{tabular}

Source: Own elaboration on the basis of the study: Danielak 2018.

It should be individually adapted to the specificity of the organization itself and the environment in which it operates. The phenomenon of the existence of relations between the organization and its stakeholders has now become one of the most important tools enabling the organization to build and manage not only the relations themselves and their value. The epidemiological situation related to the occurrence of a viral pandemic in the world has highlighted the importance and positive impact that this phenomenon may have on the competitive advantage and perception of the organization on the market. Moreover, as the practice has shown, the difficult economic situation has naturally tightened the existing bonds and deepened them by showing and giving mutual support both material and non-material. Business advantage and benefit have begun to be seen by organizations that cooperate or even compete with each other as providing mutual support for the survival of the stakeholder in a complex situation. What is more, granting various types of support has become one of the factors enabling to build a positive image of the organization and, consequently, an intangible market advantage.

\section{The impact of stakeholder relations on change and innovation management in the organisation}

Modern organizations establish and maintain relationships with other entities because the value they possess makes it easier for them to function in a competitive economy. Moreover, it enables and even facilitates stimulation or achievement of innovation. Therefore, it also has an impact on whether and how the organization manages the broadly understood process of change.

Relations with external entities, as already mentioned, are determined by a wide range of factors, but from the point of view of this article the most important is their value, i.e. the potential of the bond built. It is the one that contributes to stimulating or even initiating and further developing the organization's innovativeness. Thus, it may stimulate its propensity 
to take risks related to generating and implementing broadly understood innovations (Wiącek, 2020; Pichlak, 2012). The entity's potential for such activities is determined mainly by various factors implying changes in the organization, as well as inter-organizational relations with their network value potential (Downar, Niedzielski, 2006; Rzepka, Olak, 2017). Therefore, they usually enable, through more effective, skillful use of intangible resources such as knowledge, technology or experience, to initiate or maintain the innovativeness of the company and the potential for optimal implementation of widely understood changes. The consequence of this combination of influence is most often a significant improvement in the competitive position of such an organization (Smolarek, 2010; Tidd, Bessant, 2013; Wiącek, 2020). However, it should be stressed at this point of consideration that the contemporary understanding of the sources of innovation and change, which differs significantly from the one initially used in the literature, is very important (Smolarek, 2010; Tidd, Bessant, 2013; Wiącek, 2020). It was once believed that innovations arise only inside the organization itself and are the result of its use of various own assets. Nowadays, however, it is believed that the innovativeness of an organization is not only a result of its internal resources, but also, or rather, above all, of the optimal use of external resources coming from cooperation between enterprises (Wiącek, 2020). In order to achieve or maximize such an effect, an organization must establish and maintain relationships (Luecke, 2005; Sankowska, 2009) within the market network of economic relations in which it operates (Czakon, 2007). The organization's membership in various formal and informal business groups, such as the so-called SNA Market Networks in the literature, as well as relationship management has a positive impact on creating and implementing innovation and change (Dewick, Miozzo, 2004; Aarikka-Stenroos, Sandberg, Lehtimäki, 2014; Kim, Lui, 2015). The functioning of an organization in a network of relations, i.e., in the system of relations with other entities with which it cooperates (Czakon, 2017) significantly facilitates the innovativeness of the organization and thus the sharing of knowledge, conducting research or increasing access to resources, especially if they are unique. Such issues as dissemination on the market of information about innovations created by the organization and designed changes, i.e. promoting them, are also important for maintaining the organization's market advantage. It significantly facilitates this process and thus accelerates the benefits of sharing such business information by other entities that are co-workers of the organization and thus the previously described stakeholders. Therefore, in order to maximize the effects of its innovation, also currently called market agility, according to Czakon the organization should:

- create relationships with other organizations operating in its environment;

- ensure that all subjects of the relationship are kept separate so that each of them independently pursues their own goals;

- exchange resources by means of continuous interaction with the entities from the environment. In this way it will naturally create a common knowledge and experience base for itself and its stakeholders. The "exchange platform" that will be created in this 
way will enable synergy of strategic activities undertaken by all organizations participating in the process;

- generate innovation only through active interaction with other entities. This will create a competitive advantage created by the existence and maintenance of ties.

The way, the method by which an organization will make the described interactions is its individual, distinctive model of managing relations, changes and innovations with their potential. These activities are carried out using its unique way of interaction, coordination and effective communication (Czakon, 2017). The modern organization is therefore dependent on effective cooperation with other entities related to it in many aspects affecting its strategic advantage. On the basis of these ties, it can create and develop its own value, increase its competitiveness, and influence the facilitation of its operations in unfavorable market circumstances. Therefore, network structures and relations existing in them positively influence development and innovation. They facilitate and stimulate changes in the organization that are inseparable from innovation. These are phenomena which, as the literature indicates, are interconnected and permeate each other, significantly influencing the construction and maintenance of the strategic advantage of the organization. In the case of the change management phenomenon, a deep connection with the theory of stakeholders needs to be emphasized. Analyzing the causes of change, a common source of both phenomena is easily noticeable. It is enough to analyze the factors determining the organization's propensity to change. They are simply divided into external and internal ones (Zarębska, 2002). The internal ones, which are the result of management decisions, are aimed at further development of the organization, while the external ones are the result of events independent of the organization itself. Such events, which occurred in the environment and caused or even forced the organization to adapt. The changes taking place in the organization's environment affect all areas of its functioning. According to J. Penc, "they force a specific transformation and adjustment to the structure and potential of the environment. They cause the company to often reject what was effective in the past and even "invent" the future, transform itself and create itself anew in order to be able to realize its objectives and better serve its environment and at the same time itself" (Zając, 2006). The most important external factors causing change in the organization are presented in Table 2. Thus, external factors that are a direct source of change force the organization to strive for greater innovation. Relationships with their potential, properly used and managed, can significantly support the functioning of the organization in the situation of implementation of change or reaction to its effects if it comes from outside the organization. Another noticeable implication is the resulting conclusion that the functioning of an organization in a network of relations can contribute quite significantly to such activities. Table 3 presents a summary of a case study conducted by the author of this article in March 2019 on the example of one of the Polish organizations operating in the bottling sector. 
Table 2.

External factors causing change in the organization

\begin{tabular}{|c|c|}
\hline Company environment & Change inducing/shaping factors \\
\hline $\begin{array}{l}\text { International } \\
\text { environment }\end{array}$ & $\begin{array}{l}\text { - Political changes in Europe and the world } \\
\text { - Raw material crises } \\
\text { - Integration and disintegration processes }\end{array}$ \\
\hline $\begin{array}{l}\text { International and national } \\
\text { economic situation }\end{array}$ & $\begin{array}{l}\text { - } \quad \text { Globalisation of economies } \\
\text { - } \quad \text { Market Virtualization } \\
\text { - } \quad \text { Increased customer requirements } \\
\end{array}$ \\
\hline Legal environment & Tax, customs, labor laws that stimulate or inhibit entrepreneurship and job creation \\
\hline Market forces & $\begin{array}{l}\text { - Globalisation of markets } \\
\text { - Market Virtualization } \\
\text { - Strong increase in competition } \\
\text { - Increased customer requirements } \\
\end{array}$ \\
\hline Social and cultural trends & $\begin{array}{l}\text { - Demographic phenomena } \\
\text { - Social values } \\
\text { - Lifestyle }\end{array}$ \\
\hline Technological changes & $\begin{array}{l}\text { - } \quad \text { Rapid IT development } \\
\text { - } \\
\end{array}$ \\
\hline Ownership changes & $\begin{array}{l}\text { - Sale of companies } \\
\text { - Acquisitions, mergers } \\
\text { - Privatisation of companies }\end{array}$ \\
\hline Ecology & $\begin{array}{l}\text { - Changes in the environment } \\
\text { - Environmental legislation } \\
\text { - Eco-movements }\end{array}$ \\
\hline
\end{tabular}

Source: Own elaboration on the basis of study conducted by the author in march.2019 in one of the Polish organisations operating in the bottling sector, Wiącek 2020, Bibliography position no 27.

Table 3.

Existing relationships and their impact on company competitiveness

\begin{tabular}{|c|c|c|c|}
\hline \multicolumn{2}{|l|}{ Type of relationship } & Reasons & Impacts \\
\hline \multirow{6}{*}{ Regional Stakeholders } & \multirow[t]{3}{*}{ Consubstantial } & $\begin{array}{l}\text { availability of cheap labour } \\
\text { directly at the site of the } \\
\text { production plant }\end{array}$ & $\begin{array}{l}\text { the possibility to flexibly } \\
\text { adjust the level of } \\
\text { production and the level of } \\
\text { employment required to } \\
\text { achieve it }\end{array}$ \\
\hline & & $\begin{array}{l}\text { commitment to work - the } \\
\text { only large employer in the } \\
\text { area }\end{array}$ & lower staff turnover \\
\hline & & employment for families & \\
\hline & \multirow{3}{*}{ Contractual } & $\begin{array}{l}\text { reduction of product } \\
\text { manufacturing costs }\end{array}$ & higher final margins \\
\hline & & short delivery time & $\begin{array}{l}\text { - speeded production } \\
\text { - higher turnover of goods } \\
\text { - Speeder and more effective } \\
\text { adaptation of Krynica } \\
\text { Vitamin S.A. to the } \\
\text { changing market situation }\end{array}$ \\
\hline & & $\begin{array}{l}\text { the supplier has a stable and } \\
\text { predictable source of sales } \\
\text { of its products }\end{array}$ & $\begin{array}{l}\text { higher than the market } \\
\text { tendency for flexibility in } \\
\text { commercial cooperation } \\
\text { with the customer Krynica } \\
\text { Vitamin S.A. }\end{array}$ \\
\hline
\end{tabular}

Source: Own elaboration on the basis of study conducted by the author in march.2019 in one of the Polish organisations operating in the bottling sector, Wiącek 2020, Bibliography position no 27. 
The results of this study prove that having relations by an organization not only increases its innovativeness and competitiveness, but also facilitates the management and implementation of changes of different nature. Therefore, it is important for an organization not only to consciously establish relations, but to do so it should have knowledge about what can determine them and how they can successively influence the advantage and innovativeness. A review of the selected scientific views that link building relationships with stakeholders, their determinants and the impact on the competitive advantage of the company is presented in Table 4.

Table 4.

Determinants for strengthening competitiveness and relationship management activities

\begin{tabular}{|c|c|c|}
\hline $\begin{array}{l}\text { Type of } \\
\text { regional } \\
\text { stakeholder }\end{array}$ & $\begin{array}{l}\text { Determinants for strengthening } \\
\text { the competitiveness of the company }\end{array}$ & $\begin{array}{l}\text { Relationship management activities that } \\
\text { can provide a competitive advantage }\end{array}$ \\
\hline \multirow[t]{2}{*}{ Consubstantial } & \multirow{2}{*}{$\begin{array}{l}\text { Economies of scale, reach, increased } \\
\text { flexibility of the organization, building a } \\
\text { positive market reputation, increased } \\
\text { effectiveness of change management }\end{array}$} & $\begin{array}{l}\text { Two-way internal communication, action } \\
\text { consulting }\end{array}$ \\
\hline & & $\begin{array}{l}\text { Building commitment, empowerment in the } \\
\text { decision-making process }\end{array}$ \\
\hline \multirow[t]{2}{*}{ Contractual } & \multirow{2}{*}{$\begin{array}{l}\text { Maximize margin, reduce risk, increase } \\
\text { flexibility, accelerate response to market } \\
\text { changes, economies of scale, facilitate } \\
\text { expansion, build a positive market reputation }\end{array}$} & Creating alliances or business partnerships \\
\hline & & $\begin{array}{l}\text { Joint building of mutually beneficial } \\
\text { conditions for cooperation and development } \\
\text { of partners }\end{array}$ \\
\hline
\end{tabular}

Source: Own elaboration on the basis of study conducted by the author in march.2019 in one of the Polish organisations operating in the bottling sector, Wiącek 2020, Bibliography position no 27.

In the current market and economic situation prevailing in Poland, we can perfectly observe the materialized positive effects of the combination of relationship management with stakeholders, the functioning of enterprises in the network together with innovation and willingness to implement changes. Organizations that had relationships with their stakeholders and the ability to manage them more easily thanks to cooperation with partners coped with the difficulties of the economic situation during the pandemic.

Frequent mutual exchange of experience has led to the dumping of innovative solutions, services or products (nettg.pl, 2020; pb.pl, 2020). As a result, an increase in export dynamics was already recorded in June this year, which, as estimated by economists associated in the Polish Chamber of Commerce, was to be expected much later this year due to the global epidemiological situation (nettg.pl, 2020). Moreover, according to the projection published by the National Bank of Poland, thanks to the flexibility of Polish organizations' ability to react quickly to changes in their environment, the Polish gross domestic product, after the initial decline recorded this year, will gradually increase by $4.9 \%$ in 2021 and $3.7 \%$ in 2022 . It should also be noted that compared to the results of other EU countries, the Polish gross domestic product, which in the second quarter decreased by 8.2 percent year-on-year and 8.9 percent compared to the previous quarter, remains at a very high level (GUS, 2020). Poland recorded one of the lowest declines in the EU. Naturally, this was also influenced by an early and rapid response to the pandemic situation, the introduction of restrictions, but also - or above all - 
it was precisely the flexible, innovative, corporate behavior that made the effects of the crisis caused by the global crisis less severe. A very good example of this type of action were all those companies that started to spill disinfectants (Orlen, bottling industry, cosmetics) or sew protective masks (clothing industry) according to their own technical capabilities. To sum up, therefore, in a situation which was difficult for all market players, it was easier to cope with the survival of those who did:

- they had support from their stakeholders,

- have the inclination and courage to take the risk of innovation,

- thanks to both of the above, they were competent to implement and manage the implementation of the change efficiently and quickly.

All these phenomena as well as the way of dealing with them were a flexible response to factors from the organization's environment and derived from cooperation with stakeholders in the network.

\section{Summary}

1. The correct and accurate identification of stakeholders and the establishment of effective communication with them undoubtedly contributes to increasing the effectiveness of the strategic objectives of the company.

2. Proper management of the relations that arise between them and the organization contributes to the creation of measurable benefits for the company. It undoubtedly increases the organization's propensity for change and innovation. It brings with it the special value that they constitute in the modern economy: effective interorganizational communication, consultation, partnership and dialogue.

3. Relations - optimally maintained and managed nowadays - has a significant positive impact on the continuation of the whole company, increasing and improving its flexibility.

4. The flexible using of combination advantages of all the phenomena mentioned in the article contribute to the easier overcoming of market difficulties by the organization and may contribute to its success at the end. However, it should be emphasized that, in the author's opinion, only combined all together may provide great business success. 


\section{References}

1. Aarikka-Stenroos, L., Sandberg, B., Lehtimäki, T. (2014). Networks for the Commercialization of Innovations: A Review of how Divergent Network Actors Contribute. Industrial Marketing Management, no. 3.

2. Civera, C., Freeman, R.E. (2019). Stakeholder Relationships and Responsibilities: A New Perspective. Symphonya, Emerging Issues in Management (symphonya.unicusano.it), $1,40-58$.

3. Czakon, W. (2017). Sieci w zarządzaniu strategicznym. Warszawa: Oficyna Wydawnicza Wolters Kluwer Business.

4. Danielak, W. (2018). Zarządzanie relacjami z interesariuszami w środowisku projektowym. Wydawnictwo Politechniki Gdańskiej, 24, No. 1, 47-60.

5. Dewick, P., Miozzo, M. (2004). Networks and Innovation: Sustainable Technologies in Scottish Social Housing. R\&D Management, no. 3.

6. Donaldson, T., Preston L.E. (1995) The Stakeholder Theory of the Corporation: Concepts, Evidence, and Implications, Academy of Management Review. 20 (1): 71.

7. Downar W., Niedzielski, P. (2006). Zarządzanie interesariuszami jako instrument wspomagający realizację projektów gospodarczych w transporcie. Zeszyt Naukowy Uniwersytetu Szczecińskiego Współczesne zjawiska i procesy $w$ transporcie. Szczecin: Uniwersytet Szczeciński.

8. Freeman, R.E., Moutchnik, A. (2013). Stakeholder management and CSR: questions and answers. Umwelt Wirtschafts Forum, Vol. 21, No. 1. Springer Verlag.

9. https://nettg.pl/news/169955/polska-gospodarka-niezle-sobie-radzi-z-pandemia, 29.08.2020.

10. https://www.pb.pl/bujak-polska-gospodarka-znosi-relatywnie-dobrze-kryzys-wywolanypandemia-999402, 29.08.2020.

11. Kim, Y., Lui, S. (2015). The impacts of external network and business group on innovation: Do the types of innovation matter? Journal of Business Research, no. 9.

12. Klimas, P. (2014). Sieci innowacji. Implikacja bliskości organizacyjne. EU Publishing House in Katowice.

13. Kodama, M. (2007). Innovation and Knowledge Creation Through Leadership-based Strategic Community: Case Study on High-tech Company in Japan. Technovation, no. 3.

14. Luecke, R. (2005). Zarządzanie kreatywnością i innowacją. Czarnów: MT Biznes.

15. Pichlak, M. (2014). Wpływ otoczenia na generowanie i przyjmowanie innowacji w organizacjach. Przeglad Organizacji, $n r$ 5(892), s. 7-12, Towarzystwo Naukowe Organizacji i Kierownictwa (TNOiK), www.przegladorganizacji.pl.

16. Piwoni-Krzeszowska, E. (2013). Zarzadzanie wartościa relacji przedsiębiorstwa z rynkowymi interesariuszami. Wrocław: Publishing House of the Wrocław University of Economics. 
17. Rodriguez, M.A., Ricar, J.E. (2002). Towards the sustainable business. Revista de Antiquos Alumnos, IESE Universidad Navarra, 86, 30-32.

18. Rzepka, A., Olak, A. (2017). Wpływ relacji międzyorganizacyjnych na pobudzenie innowacyjności przedsiębiorstw. Przedsiębiorczość i Zarządzanie, Vol. XVIII, Book 4, Part I, p. 61-71, Wydawnictwo SAN.

19. Sankowska, A. (2009). Organizacja wirtualna: koncepcja i jej wpływ na innowacyjność. Warszawa: Wydawnictwo Akademickie i Profesjonalne.

20. Smolarek, M. (2010). Znaczenie zmian innowacyjnych w kontekście strategii małych i średnich przedsiębiorstw. In: P. Niedzielski, J. Guliński, K.B. Matusiak (eds.), , Zeszyty Naukowe, Kreatywność - Innowacje - Przedsiębiorczość, no. 579. Wydawnictwo Uniwersytetu Szczecińskiego.

21. Sopińska. A., Jakubowska. W. (2013). Zasoby a konkurencyjność i wyniki przedsiębiorstwa - przegląd wybranych badań. In: R. Bartkowiak, P. Wachowiak (eds.), Wiedza i bogactwo narodów. Kapitał ludzki, globalizacja i regulacja w skali światowej. Warszawa: Oficyna Wydawnicza SGH.

22. Tidd, J., Bessant, J. (2013). Zarządzanie innowacjami: integracja zmian technologicznych, rynkowych i organizacyjnych. Warszawa: Wolters Kluwer Business.

23. Walecka, A., Zakrzewska-Bielawska, A. (2013). Organizacja w procesach zmian w drodze do elastyczności i innowacyjności. In: A. Adamik (eds.), Nauka o organizacji. Ujęcie dynamiczne. Warszawa: Wolters Kluwer Business.

24. Wiącek, M. (2020). Implementation of innovative changes in Polish enterprises outline of perspectives, review of research. Internatinal Journal of Business Management and Economic Review (IJBMER), JAN-FEB, vol. 3 iss. 1, 78-96.

25. Wiącek, M. (2020). Optymalizacja procesów w przedsiębiorstwie produkcyjnym jako skutek implementacji zmiany. Dylematy $i$ wyzwania doskonalenia zarzadzania organizacjami $w$ dobie przemystu 4.0. A., Lemańska-Majdzik, M., Okręglicka, A. Korombel (eds.), cz. III, rozdział 18. Częstochowa: Wydawnictwo Politechniki Częstochowskiej; ISBN 978-83-7193-749-1.

26. Wiącek. M. (2020). Zmiany techniczno-technologiczne na tle specyfiki zjawiska zmian organizacyjnych w przedsiębiorstwach. Inżynieria Zarzadzania. Cyfryzacja Produkcji. Aktualności badawcze 2, issue I; chapter 4. Knosala R. (ed.). PWE, pp. 443-455.

27. Wiatrak, A.P. (2020). Więzi międzyorganizacyjne. Problemy zarządzania, http://pz.wz.uw.edu.pl/pl/numer/wiezi-miedzyorganizacyjne, 21.08.2020.

28. Zając, Cz. (2006). Społeczne i organizacyjne problemy przejęć i fuzji przedsiębiorstw. Wrocław, WAE.

29. Zarębska, A. (2002). Zmiany organizacyjne w przedsiębiorstwie. Warszawa, Difin.

30. Zeithaml, V. (1988). Consumer perceptions of price, quality and value: a means-end model and synthesis of evidence. Journal of Marketing, vol. 52, pp. 2-22. 